\title{
MIND MAPPING UNTUK MEMPERKAYA KOSAKATA BAHASA INGGRIS PESERTA DIDIK
}

\author{
Wiwik Yully Widyawati \\ Pendidikan Bahasa Inggris, Fakultas Bahasa dan Seni, Universitas \\ Indraprasta PGRI \\ Email : Wiwik121@gmail.com
}

\begin{abstract}
Abstrak
Penelitian ini bertujuan untuk mengetahui pengaruh Metode Mind mapping terhadap hasil belajar kosakata bahasa Inggris siswa kelas V Sekolah Dasar. Model penelitian ini menggunakan metode mirip eksperimen dengan tes pilihan ganda sebanyak 25 butir mengenai kosakata bahasa Inggris dengan menggunakan teknik pengambilan sampling secara random sampling terpilih sebanyak 29 siswa sebagai sampel. Teknik analisis data yang digunakan adalah uji-t pada taraf signifikan $\alpha=$ 0,05.Setelah peneliti meneliti Pengaruh metode Mind mapping terhadap hasil belajar kosakata bahasa Inggris, akhirnya peneliti mendapatkan kesimpulan dengan membandingkan nilai t hitung sebesar 7,19 dan t tabel 1,67 ( thitung > t tabel), berarti hipotesis yang peneliti ajukan diterima yaitu ada pengaruh metode Mind mapping yang signifikan terhadap hasil belajar kosakata bahasa Inggris. Oleh karena itu, guru disarankan untuk menggunakan metode Mind mapping untuk memperkaya kosakata bahasa inggris.
\end{abstract}

Kata Kunci : Metode, Mind mapping dan Kosakata Bahasa Inggris

\section{Abstract}

The purpose of the study is to know the effect of Mind mapping method toward the result of English Vocabbulary study for fifth grade the students of Elementary School. This method used experimental method. The writer used option test as the instrument. The sampling technique that was used in this research was random. The writer took twenty-nine students as sample. The data was analyzed by using $t$-test on the significance level $\alpha=0.05$.After the researcher had done the research about the effect of Poster' Media toward the result of vocabulary, the researcher got the conclusion by comparing the value of $t$-value $=7.19$ and $t$-table $=1.67$ ( $t$-value $>t$-table). It meant that the hypothesis which the researcher observed is accepted; there is the effect of Mind mapping method toward the result of English vocabulary. So the teacher is suggested to use the Mind mapping method to enrich the vocabulary.

Key words: Method, Mind mapping, and Vocabulary

\section{PENDAHULUAN}

Bahasa tidak hanya berasal dari kata-kata yang dikeluarkan oleh ucapan (vokal) namun juga menggunakan bahasa, isyarat atau bahasa gambar. Peradapan manusia kuno sebelum mengenal tulisan adalah menggunakan bahasa gambar. Bahasa itu sendiri berfungsi sebagai alat komunikasi yang diperggunakan secara luas dalam setiap aspek kehidupan seperti ilmu pengetahuan, pendidikan, bisnis, hiburan dan sebagainya. Selain itu, bahasa juga memiliki peran sentral dalam perkembangan intelektual, social, dan emosional peserta didik dan merupakan penunjang keberhasilan dalam mempelajari semua bidang studi. Oleh karena itu, pembelajaran bahasa diharapkan membantu peserta didik mengenal dirinya, budayanya, dan budaya orang lain. Kemudian, Pembelajaran bahasa juga membantu peserta didik mampu mengemukakan gagasan dan perasaan, berpartisipasi 
dalam masyarakat, dan bahkan menemukan serta menggunakan kemampuan analitis dan imaginatif yang ada dalam dirinya

Dalam pembelajaran bahasa anak, di Indonesia pengajarannya termasuk dalam kurikulum pembelajaran di Sekolah Dasar. Kurikulum pembelajaran bahasa terdiri dari pelajaran bahasa Indonesia sebagai mata pelajaran dasar dan mata pelajaran muatan lokal untuk pelajaran bahasa Inggris atau bahasa daerah. Untuk pelajaran bahasa Indonesia dan bahasa daerah sangat mudah dipahami oleh peserta didik Sekolah Dasar karena selalu menggunakannya dalam lingkungan sosialnya serta faktor mother tongue (tuturan asli) yang sangat akrab untuk anak. Tetapi bahasa Inggris sebagai pelajaran muatan lokal harus diajarkan secara efisien karena peserta didik Sekolah Dasar merupakan pemula (beginner). Pembelajaran bahasa di Sekolah Dasar (SD) menentukan penguasaaan bahasa yang baik dan benar oleh peserta didik dimasa yang akan datang. Hal ini disebabkan karena awal dari pembelajaran bahasa yang baik dan benar oleh peserta didik adalah di bangku Sekolah Dasar.

Hasil observasi yang dilakukan di SDN 5 Plajan Jepara, peneliti menemukan bahwa masih banyaknya peserta didik yang tidak paham dengan pembelajaran bahasa Inggris disebabkan oleh kurangnya penguasaan kosakata bahasa Inggris oleh peserta didik sehingga dalam pelajaran bahasa Inggris peserta didik merasa bosan karena merasa tidak mengerti dengan pembelajaran yang diberikan. Untuk mengatasi permasalahan tersebut, peneliti mencoba untuk menggunakan metode pembelajaran yang dapat membangkitkan gairah belajar peserta didik agar dalam pembelajaran menjadi lebih menyenangkan dan apa yang diajarkan dapat lebih dipahami yakni dengan menggunakan metode mind-mapping. Sudjana (2009:76) menyatakan, Metode mengajar adalah yang dipergunakan guru dalam mengadakan hubungan dengan siswa pada saat berlangsungnya pengajaran.

Metode MindMapping adalah metode mencatat yang sangat baik, dapat membantu siswa dalam mengingat perkataan dan bacaan, meningkatkan pemahaman terhadap materi, membantu mengorganisasi materi, dan memberikan wawasan baru. Karena dalam metode ini memanfaatkan keseluruhan otak dengan menggunakan citra visual dan prasarana grafis lainnya untuk membentuk kesan (Bobby De Porter, 1999:152 ).

Menurut Iwan Sugiarto (Agung, 2011:5) Mind Mapping merupakan suatu metode pembelajaran yang sangat baik digunakan oleh guru untuk meningkatkan daya hafal siswa dan pemahaman konsep siswa yang kuat, siswa juga dapat meningkat daya kreatifitas melalui kebebasan berimajinasi. Mind Mapping juga merupakan teknik meringkas bahan yang akan dipelajari dan memproyeksikan masalah yang dihadapi ke dalam bentuk peta atau teknik skema sehingga lebih mudah memahaminya.

Menurut Tony Buzan, Mind Maping dapat membantu kita untuk banyak hal seperti: merencanakan, berkomunikasi, menjadi lebih kreatif, 
menyelesaikan masalah, memusatkan perhatian, menyusun dan menjelaskan pikiran-pikiran, mengingat dengan baik, belajar lebih cepat dan efisien serta melatih gambar keseluruhan.

Dari beberapa definisi tersebut diatas maka dapat diambil suatu pengertian bahwa metode mind mapping adalah tehnik mencatat kreatif dalam pemetaan pikiran berbagai suatu manfaat materi pelajaran yang akan memudahkan siswa belajar. Mind mapping di kategorikan kreatif karena dalam pembuatannya, mind mapping membutuhkan pemanfaatan imajinasi dari siswa sesuai dengan tingkat kekreatifan siswa, sehingga akan mirip sebuah karya seni. Semakin siswa kreatif maka akan semakin bagus catatan siswa.

Dalam pembuatan Peta Pikiran (Mind Map) dimaksimalkan potensi pikiran manusia dengan menggunakan otak kanan yang befungsi dalam perkembangan emotional quotient (EQ) misalnya komunikasi, interaksi dengan manusia lain serta pengendalian emosi dan otak kiri yang berfungsi dalam hal-hal yang berhubungan dengan logika, rasio, kemampuan menulis dan membaca. Salah satu kegunaan dari pembuatan Peta Pikiran (Mind Map) adalah merupakan sesuatu yang menyenangkan untuk dipandan, dibaca, direnungkan dan diingat, sehingga diharapkan dengan menggunakan teknik Peta Pikiran (Mind Map) ini kesulitan menghafal kosakata Bahasa Inggris dapat teratasi.

Kemudian setelah mengetahui adanya manfaat dari metode Mindmapping ini, maka penulis melaku- kan penelitian dengan judul "Penggunaan Metode Mind-Mapping untuk Memperkaya Kosakata Bahasa Inggris." Penelitian ini bertujuan untuk Mengetahui apakah kosakata peserta didik yang menggunakan Metode Mind-Mapping lebih baik dari pada peserta didik yang tidak menggunakan Metode Mind-Mapping dan mengetahui apakah ada pengaruh penggunaan Metode MindMapping terhadap hasil belajar kosakata Bahasa Inggris peserta didik.

\section{Pengajaran Bahasa Inggris}

Suatu proses belajar harus ad interaksi anatara siswa dan guru. Hal ini harus terjadi agar dalam suatu PBM (proses belajar mengajarar) tidak terasa monoton dan hanya bisa berinterksi satu arah. Interaksi siswa dan guru yang baik akan dapat meningkatakan atau memajukan proses belajar mengajar yang baik. Interaksi ini mencakup segala hal yang terjadi dalam proses pembelajaran Saat guru menerangkan suatu pelajaran dan siswa dapat menanggapi dengan baik memperhatikan guru, ini yang disebut interaksi yang tidak monoton. Dalam hal interaksi seperti ini jika guru bertanya dan murid bisa menjawab ini juga interaksi yang tidak monoton.

Berdasarkan uraian di atas maka dalam penelitian ini dimaksud dengan interksi dalam proses pembelajaran adalah hubungan timbal balik antara guru dan siswa sehingga mendapatkan suasana yang kondusif dalam upaya memajukan suatu proses pembelajaran.

Menurut Sagala (2005:61), pembelajaran merupakan proses komunikasi dua arah antara guru 
dengan murid peserta didik. Maka, guru sebagai pendidik mendistribusikan ilmu pengetahuan yang mereka miliki kepada para peserta didik yaitu para siswa.

Sedangkan Pembelajaran diartikan oleh Gagne dan Briggs (1979:3) adalah suatu sistem yang bertujuan untuk membantu proses belajar siswa, yang berisi serangkaian peristiwa yang dirancang, disusun sedemikian rupa untuk mempengaruhi terjadinya proses belajar siswa.

Menurut Kamarudin (1993), yang dikutip dari http://carapedia.com (10 Januari 2017), pengajaran adalah suatu proses penanganan urusan untuk memungkinkan siswa mengetahui atau menyelesaikan sesuatu yang mereka tidak dapat lakukan sendiri sebelum itu. Ini berarti bahwa untuk menjadi pintar atau mengetahui halhal yang sebelumnya siswa ketahui, dibutuhkan seseorang yang membantunya, disebut seorang guru yang melakukan kegiatan membantu siswa agar lebih tahu dan kegiatan tersebut dikatakan sebagai pengajaran.

Kosakata merupakan semua kata yang terdapat dalam suatu bahasa, kekayaan kata yang dimiliki oleh seorang pembicara atau penulis. Kata yang dipakai dalam suatu bidang ilmu pengetahuan (TIM penyusun Kamus Pusat Bahasa, 1995:327), sedangkan menurut Zainuddin (1992:8), kosakata digunakan untuk mewakili suatu nama, sifat, bentuk dan jenis benda, bisa menggunakan kesatuan bahasa yang bermakna, yang disebut kata atau kelompok kata.

Kualitas keterampilan berbahasa seseorang jelas bergantung kepada kualitas dan kuantitas yang dimilikinya. Semakin kaya kosakata yang dimiliki semakin besar pula kemungkinan terampil berbahasa. Sehingga bisa dikatakan bahwa kuantitas dan kualitas, tingkatan dan kedalaman kosakata seseorang merupakan indeks pribadi yang terbaik bagi perkembangan mentalnya (Tarigan, 1993:2-3). Hal ini selaras dengan pandangan Dale dalam Tarigan (1985:3) yang memberikan pandangan tentang pentingnya memahami kosakata sebagai berikut: Kuantitas dan kualitas penguasaan kosakata seseorang merupakan indeks pribadi yang terbaik bagi perkembangan mentalnya, Perkembangan kosakata merupakan perkembangan konsep-tual, Semua pendidikan pada prinsipnya merupakan pengembang-an kosakata, Program yang sistematis bagi pengembangan kosakata dipe-ngaruhi oleh usia, jenis kelamin, kemampuan dan status sosial, Faktor geografis mempengaruhi perkem-bangan kosakata, dan Penelaahan kosakaa yang efektif hendaknya beranjak dari kata-kata yang sudah diketahui menuju kata-kata yang belum atau tidak diketahui.

Tujuan pengajaran bahasa ialah agar para siswa terampil berbahasa yang mencakup mesalah keterampilan berbicara, menyimak, membaca, dan menulis. Tidak dapat kita pungkiri lagi bahwa keterampilan berbahasa membutuhkan penguasaan kosakata yang memadai. Penguasaan kosakata yang memadai itu menentukan kualitas orang seorang dalam berbahasa dll.

Menurut Tarigan ( 1993:23), kosakata selain untuk meningkatkan kuantitas dan kualitas kosakata para siswa, namun dapat bertujuan untuk 
meningkatkan taraf kehidupan siswa, Meningkatkan taraf kemampuan mental para siswa, Meningkatkan perkembangan konseptual para siswa, Mempertajam proses berfikir kritis para siswa, dan Memperluas cakrawala pandangan hidup para siswa.

Kosakata dikelompokkan menurut jenis dan kegunaannya, dalam content word, kata-kata tersebut memiliki arti yang pasti sedangkan function word walaupun tidak memiliki arti namun berfungsi sebagai penghubung kata-kata sehingga membentuk sebuah kalimat yang memiliki arti.

Dari berbagai definisi kosakata yang dijelaskan diatas dapat disimpulkan bahwa kosakata adalah sekumpulan kata-kata yang digunakan seorang manusia untuk menyampaikan bahasa dalam kegiatan komunikasi dengan manusia lainnya.

Menurut Uno (2008:3), strategi pembelajaran merupakan cara-cara yang digunakan oleh pengajar atau guru untuk memilih kegiatan belajar yang akan digunakan selama proses pembe-lajaran. Pemilihan cara yang tepat dalam melakukan kegiatan penga-jaran, dilakukan dengan mempertimbangkan situasi dan kondisi, sumber belajar, kebutuhan dan karakteristik peserta didik yang dihadapi dalam rangka mencapai tujuan pembelajaran tertentu.

Metode pembelajaran menurut Uno (2008:3) didefinisikan sebagai cara yang digunakan guru, yang dalam menjalankan fungsinya merupakan alat untuk mencapai tujuan pembelajaran. Dapat diartikan bahwa guru dalam melakukan kegiatan pengajaran menggunakan suatu cara yang membantu meningkatkan hasil belajar siswa.

Menurut Gerlach dan Ely, 1980 seperti dikutip oleh Uno (2008:2), teknik adalah jalan, alat, atau media yang digunakan oleh guru untuk mengarahkan kegiatan peserta didik ke arah tujuan yang ingin dicapai. Arti dari teknik pembelajaran hampir sama artinya dengan metode pembelajaran dimana sebuah alat yang digunakan seorang guru dalam melakukan kegiatan pengajaran sehingga tujuan meningkatkan hasil belajar siswa dapat terwujud.

Mengutip

dari

www.klubguru.com (15 Januari

2017), pengertian dari teknik pembelajaran adalah dari metode, teknik pembelajaran diturunkan secara terapan, nyata, dan praktis di kelas saat pembelajaran berlangsung. Teknik adalah cara atau metode atau sistem mengerjakan sesuatu. Teknik dapat diartikan sebagai suatu cara yang dilakukan seorang dalam mengimplementasikan suatu metode secara spesifik, dalam kaitannya dengan proses mengajar teknik adalah cara yang kongkret yang dipakai saat proses pembelajaran berlangsung. Guru dapat berganti-ganti teknik meskipun dalam metode yang sama. Bungkus dari penerapan pendekatan, metode, dan teknik pembelajaran tersebut dinama-kan model pembelajaran. Teknik bersifat penerapan agar pembelajaran yang diberikan oleh seorang guru dapat dipahami oleh siswa dan dapat berjalan efektif. Teknik dalam pembelajaran ini guru memberikan contoh bagi siswa agar siswa dapat ikut serta dalam suatu kegiatan yang dapat merangsang berfikir dari anak itu sendiri. 
Teknik pembelajaran dapat diartikan sebagai suatu cara atau aplikasi dari metode pembelajaran yang didukung dengan strategi yang dilakukan oleh guru agar proses belajar siswa menjadi lancar dan dapat mencapai tujuan yang diinginkan bersama. Teknik pembelajaran kosakata dapat diartikan bagaimana cara agar kosakata Bahasa Inggris yang jumlahnya banyak menjadi lebih mudah, menarik dan menye-nangkan bagi siswa.

Seperti yang telah dikemukakan diatas dapat ditarik kesimpulan bahwa teknik pembelajaran adalah teknik atau cara yang digunakan oleh pengajar atau guru pada saat melakukan kegiatan pengajaran secara menarik dalam rangka mewujudkan tujuan pengajaran, salah satu metode atau teknik yang dapat digunakan adalah metode Direct Method (DM), guru melibatkan keaktifan siswa, mendengarkan pendapat dari siswa, berdiskusi dengan siswa sehingga didapatlah pemahaman yang baik terhadap suatu materi, dan salah satu teknik yang dapat dipakai dalam metode ini adalah menggambar Peta Pikiran (Mind Mapping).

Pada buku "Gembira Belajar Dengan Mind Mapping" Olivia (2008:6) menyebutkan bahwa salah satu penyebab anak sulit belajar adalah kebiasaan mereka membaca berlembar-lembar catatan hanya dalam satu malam menjelang ujian. Otak anak kesulitan "menggambarkannya" atau memvisualisasikan apa yang telah dipelajarinya karena pelajaran yang sudah dipelajari olehnya semalaman masih tidak bisa diserap dengan baik di otaknya. Otak pun memiliki keterbatasan menerima semua informasi.

Dapat diartikan bahwa otak manusia memiliki keterbatasan dalam menerima informasi, padahal dalam proses belajar di sekolah anak-anak dituntut untuk dapat menghafal banyak materi pelajaran oleh karena itu diperlukanlah sebuat teknik agar kegiatan menghafal materi pelajaran tersebut menjadi mudah dan menyenangkan.

Menurut Tony Buzan, dikutip Olivia (2008:1), terdapat kelemahan dari catatan standar (yang linear dari atas ke bawah baik satu kolom atau dua kolom) dimana sudah umum dilakukan oleh siswa SD dan cara mengatasinya, yaitu selain waktu habis hanya untuk mencari kata pengingat kunci atau kita penting. Apalagi tulisannya yang rapat tidak bisa membuat kata-kata penting tersebut jadi menonjol, kecuali bila diberi garis bawah. Kelemahan itu dapat diatasi dengan melakukan Peta Pikiran (Mind Map). Tony Buzan (seorang psikolog yang mengenalkan teknik Peta Pikiran (Mind Map) pada tahun 1970 dan mulai dikenal di Indoneisa di tahun 1990-an) mempelajari bahwa dalam menyerap informasi, orang-orang jenius seperti Albert Einstein, Leonardo Da Vinci, Pablo Picasso dan Winston Churcill memanfaatkan kedua bagian otaknya. Caranya dengan menggu-nakan gambar-gambar atau apa yang disebut dengan memori fotografi. Jadi bagaikan seorang fotografer yang mampu merekam momen atau situasi dalam foto. Menurut Tony Buzan dengan memanfaatkan gambar dan teks ketika seseorang mencatat atau mengeluarkan suatu ide yang ada di dalam pikiran, maka kita telah 
menggunakan dua belahan otak secara sinergis. Apalagi jika dalam peta pikiran itu kemudian ditambahkan warna-warna dan halhal yang memperkuat emosi.

Teknik Mind Mapping adalah sebuah teknik baru yang menggunakan gambar serta teks dalam membantu siswa dalam menghafal materi pelajaran, teknik ini dilakukan dengan menggunakan secara maksimal kedua belahan otak manusia.

Menurut Martin sebagaimana diterjemahkan ke dalam Bahasa Indonesia Trianto (2009:158) pemetaan pikiran adalah ilustrasi grafis konkret yang menunjukkan bagaimana satu konsep terkait dengan konsep lainnya dalam kategori yang sama. Pemetaan pikiran adalah pola yang setidaknya terdiri dari gambar, simbol dan warna yang tidak hanya membantu siswa untuk memahami pengetahuan kosakata tetapi juga membuat siswa merasa nyaman, menyenangkan dan menarik otak mereka yang akhirnya membuat mereka memiliki minat dalam pengetahuan kosakata penguasaan.

Menurut Buzan (2008:9), pengertian Peta Pikiran (Mind Map) adalah peta perjalanan yang hebat bagi ingatan, dengan memberikan kemudahan kepada kita dalam mengatur segala fakta dan hasil pemikiran dengan cara sedemikian rupa sehingga cara kerja alami otak kita dilibatkan dari awal. Ini berarti bahwa upaya untuk mengingat (remembering) dan menarik kembali (recalling) informasi di kemudian hari akan lebih mudah, serta lebih dapat diandalkan daripada bila menggunakan cara pencatatan tradisional. Ditambahkan bahwa Peta Pikiran (Mind Map) adalah cara paling mudah untuk memasukkan informasi ke dalam otak, dan untuk mengambil informasi dari otak. Peta Pikiran (Mind Map) memberikan beberapa kegunaan yaitu: 1) Memberikan ringkasan atas suatu subjek atau area yang luas, 2) Memudahkan kita membuat rencana perjalanan atau suatu pilihan, dan membatu kita mengetahui tujuan kita dan posisi kita sekarang, 3) Mengumpulkan sejumlah besar data dan meletakannya di satu tempat, 4) Memberi dorongan atas upaya pemecahan masalah dengan memberika kesempatan untuk melihat jalan-jalan keluar kreatif yang baru, 5) Merupakan sesuatu yang menyenangkan untuk dipandan, dibaca, direnungkan dan diingat.

Peta Pikiran (Mind Map) dapat memudahkan siswa dalam menghafal suatu materi pelajaran dengan cara membuat catatan menarik, menggunakan gambargambar yang mudah diingat. Banyak kegunaan dari Peta Pikiran (Mind Map) antara lain adalah memberikan sebuah solusi mudah dan menarik dari masalah kesulitan menghafal materi pelajaran yang banyak dimiliki oleh siswa.

Peta Pikiran (Mind Map) sangat bermanfaat dalam kegiatan apapun. Seperti yang diungkapkan oleh Porter \& Hernacki (2002:172), bahwa pemetaan pikiran (Mind Map) memiliki beberapa manfaat sebagai berikut: 1) Dengan membuat Peta Pikiran (Mind Map), membantu kita untuk berkonsentrasi pada gagasan yang dicari, sehingga tidak perlu berpikir untuk menangkap setiap kata yang dibicarakan, 2) Ketika membaca suatu tulisan, Peta Pikiran (Mind Map) akan meningkatkan 
pemahaman dan memberikan catatan tinjauan ulang yang sangat berarti, 3) Dengan menggunakan Peta Pikiran (Mind Map), imajinasi dan kreativitas kita tidak terbatas, 4) Ditambah dengan Peta Pikiran (Mind Map) yang memadukan simbol, gambar, dan warna menjadikan pembelajaran apapun menjadi lebih menyenangkan dan tidak membo-sankan.

Peta Pikiran (Mind Map) sangat membantu siswa dalam hal menghafal materi pelajaran yang sudah tidak sedikit jumlahnya. Peta Pikiran (Mind Map) adalah cara mencatat yang mudah dan menarik dengan memadukan unsur teks serta gambar yang dibuat warna-warni sehingga jika diperlukan kembali, catatan tersebut dapat mempermudah siswa yang membacanya.

Peta Pikiran (Mind Map) memiliki bebeapa manfaat, seperti yang dikemukakan oleh Waruru (2008) manfaat Peta Pikiran (Mind Map) antara lain: 1) Memberi pandangan menyeluruh pokok masalah atau area yang luas, 2) Memungkinkan kita merencanakan rute atau membuat pilihan-pilihan dan mengetahui kemana kita akan pergi dan dimana kita berada, 3) Mengumpulkan sejumlah besar data disatu tempat, 4) Mendorong pemecahan masalah dengan membiarkan kita melihat jalan-jalan kreatif baru, 5) Menyenangkan untuk dilihat, dibaca, dicerna, dan diingat.

Banyak manfaat yang diberikan dari Peta Pikiran (Mind Map) antara lain adalah membuat catatan yang menarik dan mudah diingat karena mudah dibaca dan di cerna.

Dari uraian diatas dapat disimpulkan bahwa terdapat banyak manfaat yang didapatkan dengan mencatat menggunakan Peta Pikiran (Mind Map) yaitu Peta Pikiran (Mind Map) membantu siswa membuat catatan yang mudah diingat sewaktuwaktu sehingga siswa tidak hanya menghafal namun memahami sebuah kosakata dengan mengingat kata kunci dari kosakata tersebut yang digambarkan dengan gambar yang semenarik mungkin, dan juga menambah kemampuan siswa dalam berimajinasi, dan berkonsentrasi, bukan hanya itu saja Peta Pikiran (Mind Map) juga dapat merangsang sisi kreatif siswa dan berpikir kritis lewat penggunakan garis lengkung, warna dan gambar, kemampuan siswa dalam berimajinasi dan berkonsentrasi pun dapat bertambah dengan penggunaan Peta Pikiran (Mind Map) ini.

Sehingga menurut penulis kekurangan dari Peta Pikiran (Mind Map) berhubungan dengan proses belajar mengajar di kelas dapat diatasi dengan berbagai cara antara lain, guru harus selalu memper-hatikan semua siswanya agar semua bisa terlibat dalam proses belajar mengajar kemudian jika terlihat ada siswa yang tidak aktif, guru yang harus aktif untuk bertanya atau memberikan kesempatan kepada siswa yang tidak aktif tersebut untuk memberikan pendapat atau gagasannya, perlu ditambahkan lagi bahwa Guru harus selalu mengajar-kan siswa untuk selalu berfikir secara menyebar, sehingga siswa dapat dengan mudah menjabarkan sebuah ide pokok yang selanjutnya dapat mereka gambarkan pada Peta Pikiran (Mind Map), sarana dan prasarana dari guru dan sekolah dalam mengajarkan siswa melalui program komputer cara membuat 
Peta Pikiran (Mind Map) yang baik dengan memberikan tambahan materi pada pelajaran pengenalan komputer juga diperlukan.

Menurut Buzan (2008:21) menerangkan terdapat tujuh langkah dalam pembuatan Peta Pikiran (Mind Map), yaitu: ada tujuh langkah cara membuat Peta Pikiran (Mind Map), yaitu: 1) Memulai dari bagian tengah permukaan secarik kertas kosong yang diletakkan dalam posisi memanjang. Dengan memulai dari tengah-tengah permukaan kertas akan memberikan keleluasaan bagi cara kerja otak untuk memencar keluar ke segala arah, dan mengekspresikan diri lebih bebas dan alami, 2) Menggunakan sebuah gambar untuk gagasan pusat. Karena suatu gambar bernilai seribu kata dan membantu memunculkan imajinasi. Gambar yang letaknya ditengah-tengah akan lebih menarik, membuat penulis fokus, membantu penulis memusatkan pikiran, dan membuat otak semakin aktif dan sibuk, 3) Menggunakan warna pada seluruh Peta Pikiran (Mind Map), warna akan membuat Peta Pikiran (Mind Map), tampak lebih cerah dan hidup, meningkatkan kekuatan dahsyat bagi cara berpikir kreatif, 4) Menghubungkan cabang-cabang utama ke gambar sentral dan menghubungkan cabang-cabang tingkat kedua dan ketiga pada tingkat pertama dan kedua, dan seterusnya. Hal ini dilakukan karena seperti yang telah kita ketahui, otak bekerja dengan menggunakan asosiasi. Jika kita menghubungkan cabang-cabang kita akan jauh lebih mudah dlm memahami dan mengingat, 5) Membuat cabang-cabang Peta Pikiran (Mind Map) membentuk meleng- kung. Cabang-cabang dibuat melengkung agar menghilangkan kebosanan pada otak dan merangsang sisi kreatifitas dan otak kanan. Cabangcabang yang melengkung menimbulkan kesan yang lebih menarik bila dibanding garis lurus, 5) Menggunakan satu kata kunci per baris. Kata kunci tunggal akan membuat Peta Pikiran (Mind Map) lebih kuat dan fleksibel, 7) Menggunakan gambar pada seluruh Peta Pikiran (Mind Map). Dalam setiap gambar bernilai seribu kata".

Inti dari Peta Pikiran (Mind Map) adalah imajinasi dan asosiasi. Dijelaskan pada Buzan (2008: 19): penggunaan imajinasi membantu siswa mengingat karena imajinasi membuat segala sesuatu tampak lebih menarik dan semakin menarik akan semakin mudah diingat. Asosiasi adalah cara menghubung-hubungkan apa yang diketahui. Sebagai contoh jika kita membaca kata "BUAH" yang tercetak dengan huruf kapital dan segera tutup kedua mata kita dalam beberapa menit, pada saat menutup mata apakah yang tergambar dalam otak kita adalah rangkaian huruf B-U-A-H, tentu tidak melainkan segala sesuatu yang berhubungan dengan buah, seperti gambar buah kesukaan kita, atau semangkuk buah, atau toko buahbuahan dan sebagainya. Mungkin juga kita bisa melihat warna-warna dari berbagai macam buah yang berlainan, mengasosiasikan warnawarna tersebut dengan rasa buah tertentu. Otak kita menggunakan gambar-gambar dihubungkan dengan sebuah asosiasi yang memencar secara otomatis dari pikiran tersebut. 


\section{METODE}

Desain yang digunakan dalam metode penelitian ini meng-gunakan mirip eksperimen (quasi experiment). Dalam penelitian ini penulis menggunakan desain praeksperimental dimana menggunakan satu variabel bebas dengan tidak memasukkan kelompok kontrol dan menggunakan tes awal-tes akhir kelompok tunggal (the one group pretest-posttest).

Di SDN 5 Plajan sebagai tempat penelitian berlangsung kelas $\mathrm{V}$ hanya ada satu kelas sehingga hanya ada kelompok eksperimental atau kelompok yang diberikan perlakuan tidak ada kelompok kontrol atau kelompok yang tidak diberikan perlakuan. Namun dalam penelitian yang dilakukan oleh penulis ini, penulis menggunakan desain yang disebut desain tes awal - tes akhir kelompok tunggal (The One Group Pratest-Posttest).

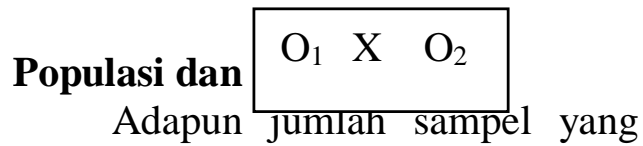
digunakan dalam penelitian ini adalah 29 peserta didik.. Dalam penelitian ini penulis mencoba membandingkan dan meneliti seberapa besar pengaruh yang dihasilkan terhadap hasil kosakata peserta didik yang diajar dengan menggunakan metode Mind mapping dengan peserta didik yang diajar dengan menggunakan media

\section{Teknik Analisis Prasyarat Data}

Sebelum data dianalisis untuk pengujian hipotesis, berdasarkan data yang terkumpul dari hasil terhadap data tersebut terlebih dahulu dilakukan diuji prasyarat analisis
Dengan skema adalah :

Keterangan :

$\mathrm{O}_{1}=$ Kondisi awal

$\mathrm{X}=$ Perlakuan

$\mathrm{O}_{2}=$ Kondisi setelah perlakuan

Untuk menggunakan

desain ini penulis membandingkan hasil belajar kosakata Bahasa Inggris sebelum memperoleh pengetahuan tentang teknik Mind Mapping dengan hasil belajar kosakata Bahasa Inggris setelah memperoleh pengetahuan tentang teknik Mind Mapping.

Kemudian, penulis mengadakan sebuah Tes untuk mengukur hasil belajar kosakata siswa berupa soal pilihan ganda sebanyak 25 butir soal. Soal-soal tersebut diberikan kepada siswa kelas V SDN 5 Plajan Jepara.

data, yaitu uji normalitas dan uji homogenitas. 
BAHTERA: Jurnal Pendidikan Bahasa dan Sastra, Volume 16 Nomor 1 Januari 2017 http://journal.unj.ac.id/unj/index.php/bahtera/

ISSN : 0853-2710

\section{HASIL DAN PEMBAHASAN}

Berikut ini adalah deskripsi Inggris yang menggunakan metode data Hasil Belajar Kosakata Bahasa Mind mapping.

Tabel 1

Tabel Distribusi Frekuensi Nilai Hasil Post Test

\begin{tabular}{|c|c|c|c|c|c|}
\hline Nilai & $\boldsymbol{f}_{\boldsymbol{i}}$ & $\boldsymbol{x}_{\boldsymbol{i}}$ & $\boldsymbol{f}_{\boldsymbol{i} . \boldsymbol{x}_{\boldsymbol{i}}}$ & $\boldsymbol{x}_{\boldsymbol{1}}{ }^{\mathbf{2}}$ & $\boldsymbol{f}_{\boldsymbol{1}} \cdot \boldsymbol{x}_{\boldsymbol{I}}{ }^{\mathbf{2}}$ \\
\hline $60-64$ & 6 & 62 & 372 & 3844 & 23064 \\
\hline $65-69$ & 3 & 67 & 201 & 4489 & 13467 \\
\hline $\mathbf{7 0}-\mathbf{7 4}$ & $\mathbf{7}$ & $\mathbf{7 2}$ & $\mathbf{5 0 4}$ & $\mathbf{5 1 8 4}$ & $\mathbf{3 6 2 8 8}$ \\
\hline $75-79$ & 4 & 77 & 308 & 5929 & 23716 \\
\hline $80-84$ & 6 & 82 & 492 & 6724 & 40344 \\
\hline $85-89$ & 2 & 87 & 174 & 7569 & 15138 \\
\hline $90-94$ & 1 & 92 & 92 & 8464 & 8464 \\
\hline Jumlah & 29 & 539 & 2143 & 42203 & 160481 \\
\hline
\end{tabular}

Tabel 2

Tabel Distribusi Frekuensi Nilai Hasil Pre Test

\begin{tabular}{|c|c|c|c|c|c|}
\hline Nilai & $\boldsymbol{f}_{\boldsymbol{i}}$ & $\boldsymbol{x}_{\boldsymbol{i}}$ & $\boldsymbol{f}_{\boldsymbol{i} . \boldsymbol{x}_{\boldsymbol{i}}}$ & $\boldsymbol{x}_{\boldsymbol{I}}{ }^{2}$ & $\boldsymbol{f}_{\boldsymbol{I}} \cdot \boldsymbol{x}_{\boldsymbol{I}}{ }^{2}$ \\
\hline $40-46$ & 3 & 43 & 129 & 1849 & 5547 \\
\hline $47-53$ & 6 & 50 & 300 & 2500 & 15000 \\
\hline $54-60$ & 9 & 57 & 513 & 3249 & 29241 \\
\hline $61-67$ & 8 & 64 & 512 & 4096 & 32768 \\
\hline $68-74$ & 2 & 71 & 142 & 5041 & 10082 \\
\hline $75-81$ & 1 & 78 & 78 & 6084 & 6084 \\
\hline Jumlah & 29 & 363 & 1674 & 22819 & 98722 \\
\hline
\end{tabular}




\section{Analisis Persyaratan Data}

1. Uji Normalitas (Uji Lilliefors) Data Hasil Post Test $\left(\mathrm{X}_{1}\right)$.

Berdasarkan tabel yang ada dilampiran, diketahui Dengan Mean adalah 73,90 dan Standar Deviasi sebesar 8,7 sehingga didapat harga $\mathrm{L}_{\mathrm{h}}=0,1388$. Kemudian diperoleh bahwa harga $\mathrm{L}$ tabel $\left(\mathrm{L}_{\mathrm{t}}\right)$ dengan $\alpha=95 \%$ dan $\mathrm{N}=29$ adalah $\mathrm{L}_{\mathrm{t}}(0,05 ; 29)=0,160$. Dengan demikian, karena $\mathrm{L}_{\mathrm{h}}=0,1388$ kurang dari $\mathrm{L}_{\mathrm{t}}(0,05 ; 29)=0,160$, maka data adalah berdistribusi normal.

2. Uji Normalitas (Uji Lilliefors) Data Hasil Pre Test $\left(\mathrm{X}_{2}\right)$

Berdasarkan tabel yang terlampir, diketahui Dengan Mean adalah 57,72 dan Standar Deviasi sebesar 8,64 sehingga didapat harga $\mathrm{L}_{\mathrm{h}}=0,1310$. Kemudian diperoleh bahwa harga $\mathrm{L}$ tabel $\left(\mathrm{L}_{\mathrm{t}}\right)$ dengan $\alpha=95 \%$ dan $\mathrm{N}=29$ adalah $L_{t}(0,05 ; 29)=0,160$. Dengan demikian, karena $\mathrm{L}_{\mathrm{h}}=0,1310$ kurang dari $\mathrm{L}_{\mathrm{t}}(0,05 ; 29)=0,160$, maka data adalah berdistribusi normal.

3. Uji Homogenitas (Uji F Fitung)

Jika $F_{\text {hitung }}<\mathrm{F}_{\text {tabel, }}$, berarti homogen dan Jika $F_{\text {hitung }}>F_{\text {tabel, }}$ berarti tidak homogen. Didapat $F_{\text {tabel }}$ sebesar 1,88. Sehingga dapat disimpulkan bahwa $\mathrm{F}_{\text {hitung }}<\mathrm{F}_{\text {tabel }}, 1,014<1,88$, berarti homogen.

\section{Pengujian Hipotesis Penelitian}

Dalam menarik kesimpulan mengenai uji hipotesis penelitian, dapat dikatakan bahwa $t_{\text {hitung }}$ sebesar 7,19 $>\mathrm{t}_{\text {tabel }}$ sebesar 1,674 (dengan nilai dk $\left(\mathrm{n}_{1}+\mathrm{n}_{2}-2\right.$ $=29+29-2=56$ ), hasilnya signifikan, karena peneliti melihat rata-rata nilai post test yaitu test yang dilakukan setelah diberikan perlakuan teknik Mind Mapping kepada siswa kelas V SDN 5 Plajan Jepara lebih besar dari pada nilai pre test yaitu test yang dilaku-kan sebelum diberikan perlakuan teknik Mind Mapping dalam kegiatan belajar mengajar. Oleh karena itu peneliti mengambil kesimpulan bahwa ada pengaruh antara teknik Mind Mapping terhadap hasil belajar kosakata Bahasa
Inggris yang diterapkan pada siswa kelas $\mathrm{V}$ SDN5 Plajan Jepara.

Setelah dilakukan penelitian berupa pemberian perlakuan teknik Mind Mapping pada kegiatan belajar mengajar siswa kelas V SDN 5 Plajan dapat dilihat hasilnya dari tes yang diberikan peneliti kepada sampel yang diambil yaitu seluruh siswa kelas V SDN 5 Plajan yang berjumlah 29 orang. Tes yang dilakukan adalah pre test, yaitu tes yang dilakukan sebelum diberikan perlakuan teknik Mind Mapping pada kegiatan belajar mengajar, dan post test, yaitu tes yang dilakukan setelah diberikan perlakuan teknik Mind Mapping. Pada nilai hasil post test didapat rata-rata sebesar 73,90 , median sebesar 73,43, nilai modus yaitu 72 dan nilai standar deviasinya adalah 8,7 . Sedangkan pada nilai hasil pre test didapat rata-rata sebesar 57,72, median sebesar 57,78, nilai modus sebesar 58,75 dan nilai standar deviasinya adalah 8,64.

Oleh karena nilai rata-rata hasil post test lebih besar daripada nilai hasil pre test, peneliti menyimpulkan bahwa ada pengaruh antara antara teknik Mind Mapping terhadap hasil belajar kosakata Bahasa Inggris yang diterapkan pada siswa kelas V SDN 5 Plajan Jepara. Dengan demikian, guru dapat menggu-nakan metode Mind-mapping dalam kegiatan belajar mengajar karena metode pembelajaran ini memiliki pengaruh yang positif untuk meningkatkan pengu-asaan kosakata bahasa Inggris siswa SDN 5 Plajan Jepara.

\section{SIMPULAN}

Berdasarkan hasil penelitian dan pengujian persyaratan hipotesis, maka dapat disimpulkan hasil penelitian secara signifikan menolak $\mathrm{H}_{0}$, itu berarti bahwa $\mathrm{H}_{1}$ diterima yang menyatakan bahwa ada pengaruh teknik peta pikiran terhadap hasil belajar kosakata Bahasa Inggris siswa kelas V SDN 5 Plajan. Selain itu dapat disimpulkan juga bahwa pemilihan teknik belajar yang baik dan tepat dapat memacu peserta didik dalam meningkatkan hasil kosakata Bahasa Inggris, salah satunya 
adalah teknik Peta Mind Mapping. Hal ini dapat dilihat dari hasil nilai peserta didik setelah dilakukan perlakuan dengan menggunakan metode mind mapping yaitu dihasilkan bahwa pada nilai hasil post test didapat rata-rata sebesar 73,90 , median sebesar 73,43, nilai modus yaitu 72 dan nilai standar deviasinya adalah 8,7. Sedangkan pada nilai hasil pre test didapat rata-rata sebesar 57,72, median sebesar 57,78 , nilai modus sebesar 58,75 dan nilai standar deviasinya adalah 8,64.

Melihat hasil di atas dapat disimpulkan bahwa penggunaan teknik / metode mind mapping memiliki pengaruh terhadap hasil belajar kosakata bahasa Inggris, ini dibuktikan dari hasil uji-t pada taraf signifikasi $\alpha=0,05$ diperoleh thitung sebesar 7,19 dan t tabel sebesar 1,67

Dalam rangka meningkatkan hasil belajar siswa dan keberhasilan terhadap hasil belajar kosakata bahasa Inggris, maka penulis memberikan saran sebagai berikut : 1. Dalam pengajaran bahasa Inggris khususnya belajar kosakata bahasa Inggris diharapkan guru menggunakan Teknik Mind-Mapping (Peta Pikiran) sebagai alternatif dalam mengajar bahasa inggris agar peserta didik tidak mudah bosan, termotivasi untuk belajar dan pembelajaran menjadi lebih menyenangkan agar peserta didik dapat menguasai koasakata bahasa Inggris dengan mudah sehingga kosakata mereka menjadi banyak.

2. Bagi orangtua diharapkan dapat bekejasama dengan pendidik dalm membimbing dan memberikan motivasi yang tinggi terhadap para peserta didik.

\section{REFERENSI}

Hamzah B. Uno, 2008. Model Pembelajaran (Menciptakan Proses Belajar Mengajar yang kreatif dan efektif). Jakarta. Bumi Aksara.

Olivia, Femmy. 2008. Gembira Belajar Dengan Mind Mapping. Jakarta. PT Elex Media Komputindo.
Richard, C. Jack \& Rogers, Theodore S. 1992. Approaching and methods in Language Teaching. Cambridge University Press.

Sudjana, Nana. 2005. Dasar-Dasar Proses Belajar Mengajar. Bandung. Sinar Baru Algesindo.

Syaiful, Sagala. 2005. Konsep dan Makna Pembelajaran. Bandung. CV. Alfabeta.

Tarigan, Henry. 1985. Penggalan Kosakata. Jakarta: Rineka Cipta

Tarigan, Henry. 1993. Pengajaran Kosakata. Jakarta: Rineka Cipta

Trianto, M.Pd. 2009. Mendesain Model Pembelajaran Inovatif: Konsep, Landasan, dan Implementasinya pada Kurikulum ingkat Satuan Dasar Pendidikan (KTSP). Jakarta. Kencana

Tim Redaksi Fokus Media. 2008. UndangUndang Guru dan Dosen. Bandung. Fokus Media.

Ur, Penny. 1996. A Course in Language Teaching. New York. Cambridge University Press.

Wiersma, William. 1991. Research Methods in Education. Boston. Allyn and Bacon. 